\title{
EGFR NM_005228.3:C.334_1137del804
}

National Cancer Institute

\section{Source}

National Cancer Institute. EGFR NM 005228.3:C.334 1137del804. NCI Thesaurus. Code C101139.

A deletion of exons 2-7 of the EGFR gene corresponding to 804 nucleotides starting at position 334 through position 1137. 